\section{Assessing a Garden-based Curriculum for Elementary Youth in lowa: Parental Perceptions of Change}

\author{
Kimberly R. Hilgers ${ }^{1,3,5}$, Cynthia Haynes ${ }^{1,4,6}$, and Joanne Olson ${ }^{2,4}$
}

ADDITIONAL INDEX WORDs. survey, nutrition, science, environmental awareness

Summary. The interest and use of gardens as educational tools for youth has increased in recent decades. The positive connection found between children and horticulture has prompted the development of garden-based curricula for use in schools. Iowa State University Extension developed the Growing in the Garden (GITG) curriculum for use in kindergarten through third-grade classrooms. This study examined what impact the GITG curriculum had on the awareness and interest of first graders in the areas of science, nutrition, and environmental awareness. Impact was assessed by a parental survey asking for perceptions of their child's interest and awareness after experiencing three lessons from the GITG curriculum. The sample population consisted of 78 parents of

first-grade students from four classrooms in Iowa. The response rate was $\mathbf{6 0 . 2 \%}$. Results indicate that a significant number of parents completing the survey noted an increased awareness and interest of their children in the areas of science and the environment. Factors such as socioeconomic status, ethnicity, and gender did not influence the outcomes.

$\mathrm{T}$ The interest and use of gardens as educational tools for youth has increased in recent decades (Dirks and Orvis, 2005; Lineberger and Zajicek, 2000). As the interest in school gardens has increased, so have the number of research studies relating to children and horticulture. Many studies relate to psychological and emotional responses of people to plant interactions (Relf and Lohr, 2003). Research points to the presence of plant material as therapeutic, improving concentration and behavior of children with attention deficit disorder (Taylor et al., 2001; Wells, 2000). Rahm (1999) showed that youth gained appreciation and awareness for the natural world through their garden-based activities. Horticulture has also been used as a tool to improve attitudes of youth at risk (McGuinn and Relf, 2001).

\footnotetext{
We gratefully acknowledge Sue Cook for her assistance with lesson implementation and Janet Anderson for useful discussions.

${ }^{1}$ Department of Horticulture, Iowa State University, Ames, IA 50011-1100

${ }^{2}$ Department of Curriculum and Instruction, Iowa State University, Ames, IA 50011-1100

${ }^{3}$ Graduate student

${ }^{4}$ Associate professor.

${ }^{5}$ Current address: Department of Horticulture, Forestry, Landscape, and Parks, South Dakota State University, Brookings, SD 57007-0996.

${ }^{6}$ Corresponding author. E-mail: chaynes@iastate.edu.
}

Because research has shown that negative attitudes toward science are developed before students reach high school (Gilroy, 2002), many gardenbased curricula include lessons based on local or national science standards. Garden-based curricula offer opportunities to experience scientific concepts (Mohrmann, 1999). Hands-on experimentation may motivate student learning and make science lessons more meaningful (Scruggs and Mastropieri, 1995). Marginal evidence of increased science achievement has been shown with the Junior Master Gardener (JMG) (Klemmer et al., 2005; Smith and Motsenbocker, 2005).

Attitudes toward the environment begin developing very early in life, before adolescence (Campbell et al., 1997). Implementation of environmental programs can foster an appreciation of the environment (Rahm, 1999). The presence and interaction with a children's garden resulted in knowledge gain and respect for the environment in preschoolers (Midden and Chambers, 2000). Skelly and Zajicek (1998) reported an increase in positive environmental attitudes of second- and fourth-grade students participating in a garden-based curriculum.

Because food is almost wholly derived, ultimately, from plants, garden-based curriculum may be an effective way to teach nutrition (Morris and Zindenberg-Cherr, 2002). Schools play a critical role in nutrition education not only to encourage physical health of students but also to increase educational achievement promoted by proper nutrition (Briggs et al., 2003). School gardens can improve nutritional knowledge and preferences for vegetables and fruit (respectively) in elementary students (Grahm et al., 2005, Koch et al., 2005). In California, a school that combined a gardening program with nutritional education saw a $10 \%$ increase in fruit and vegetable consumption among participants (Twiss et al., 2003). Morris and ZindenbergCherr (2002) concluded that nutritional lessons supplemented with garden-based activities significantly increased a preference for certain vegetables and maintained their significance at a 6-month follow-up.

The positive connections found between children and horticulture have prompted the development of garden-based curricula such as GrowLab, from the National Gardening Association, and the JMG program, from Texas A\&M University (Meyer et al., 2001). The JMG program is the most highly researched of the youth garden curricula and is nationally implemented by at least 28 university extension cooperatives (Dirks and Orvis, 2005; Meyer et al., 2001; Motsenbocker and Smith, 2003; O'Callaghan, 2005; Smith and Motsenbocker, 2005; Texas A\&M University Extension, 2005). Developed in 1999, the program is designed for youth ages 9 to 19 years old and incorporates many scholastic disciplines as well as leadership and life skills in its primarily horticultural and environmental lessons (Welsh et al., 1999).

At about the same time, Iowa State University developed the Growing in the Garden (GITG) curriculum. It was piloted in 1998 and 1999 and was made available throughout Iowa in 2000. In 2003, the GITG curriculum was identified as one of the top new gardening programs by the National Gardening Association (Iowa State University Extension, 2001). Since its inception, nearly 2900 teachers in Iowa have been provided with professional development sessions in lesson implementation and have offered information on unit connectivity to standards and 
benchmarks. The curriculum is now available nationwide.

Unlike many garden-based curricula, GITG was designed for use in a classroom setting while allowing for expansion into a garden environment. The GITG program targets early elementary (kindergarten through thirdgrade) students, which is a younger audience than most other gardening curricula.

Assessing an audience so young can be challenging. Children between the ages of 5 and 8 years vary greatly in their cognitive abilities and motor skill development, making traditional paper and pencil assessment problematic (Doak and Chapman, 1994). Although observation is a popular means of assessing young children (Criswell and Criswell, 1995), classroom time constraints make individual student assessment by teachers difficult to conduct. Boudreau (2005) found parental questionnaires, an alternative assessment method, reliable compared with more formal literacy testing in young children. Parental observation also allows for evaluation of interest and behaviors outside of the school environment, thus assessing the important transfer of learning to nonschool context. The possibility exists, however, for more responses from parents that are highly involved with their child's schooling than those that are less involved.

Research and evaluation of a curriculum allows teachers to determine impact before allocating precious time or money to new programs (DeMarco et al., 1999; Klemmer et al., 2005; Phibbs and Relf, 2005). It is anticipated that connections between research-supported impacts of GITG and instructional objectives may increase the effective use of the curriculum by schools. Therefore, the objective of this study was to examine the impact of the GITG curriculum on the interest and awareness of first graders in the areas of science, nutrition, and environmental awareness.

\section{Materials and methods}

Survey Development. Assessment of impact was determined by a survey of parental perceptions of their child's behavior after the child experienced three lessons from the GITG curriculum. The survey instrument contained 12 yes/no questions with space provided after each question for additional comments, thoughts, or observations. Four questions were developed in each of the three areas of science, nutrition, and environmental awareness (Table 1). These questions

Table 1. Sign test results and proportion of positive (yes) responses from a garden-based curriculum assessment survey.

\begin{tabular}{|c|c|c|c|c|}
\hline \multirow[b]{2}{*}{ Category and question } & \multicolumn{4}{|c|}{ Responses } \\
\hline & $\bar{n}$ & Missing (n) & Positive (\%) & $P$ \\
\hline \multicolumn{5}{|l|}{ Science } \\
\hline $\begin{array}{l}\text { a) Has your child shown an increased interest in the origin of } \\
\text { their foods, such as which part of a plant is eaten or if food is } \\
\text { from plants or animals? }\end{array}$ & 45 & 2 & 37.8 & 0.135 \\
\hline $\begin{array}{l}\text { b) Has your child shown an increased ability to distinguish } \\
\text { between living and nonliving things? }\end{array}$ & 45 & 2 & 80.0 & $<0.001^{*}$ \\
\hline $\begin{array}{l}\text { c) Has your child shown an increased interest in searching for } \\
\text { explanations to their questions? }\end{array}$ & 45 & 2 & 75.6 & $<0.001^{*}$ \\
\hline $\begin{array}{l}\text { d) Has your child shown an increased interest in the } \\
\text { identification or names of plants? }\end{array}$ & 46 & 1 & 43.5 & 0.461 \\
\hline \multicolumn{5}{|l|}{ Nutrition } \\
\hline $\begin{array}{l}\text { a) Has your child shown an increased interest in eating or at least } \\
\text { trying new fruits or vegetables at home or at restaurants? }\end{array}$ & 47 & 0 & 59.6 & 0.243 \\
\hline $\begin{array}{l}\text { b) Has your child shown an increased interest in produce when at } \\
\text { the grocery store or market such as what something is or } \\
\text { where it is grown? }\end{array}$ & 46 & 1 & 50.0 & 1.0 \\
\hline $\begin{array}{l}\text { c) Has your child shown an increased interest in identifying the } \\
\text { food groups represented at meals or snack time? }\end{array}$ & 46 & 1 & 45.7 & 0.659 \\
\hline $\begin{array}{l}\text { d) Has your child shown an increased interest in packaged food } \\
\text { products such as what it is made out of (e.g., pasta = rains) or } \\
\text { which food group it is in? }\end{array}$ & 46 & 1 & 21.7 & $<0.001^{*}$ \\
\hline \multicolumn{5}{|l|}{ Environmental awareness } \\
\hline $\begin{array}{l}\text { a) Has your child shown an increased respect for landscape } \\
\text { plantings such as walking around or stepping over } \\
\text { planted areas? }\end{array}$ & 47 & 0 & 78.7 & $<0.001^{*}$ \\
\hline $\begin{array}{l}\text { b) Has your child shown an increased awareness of } \\
\text { environmental issues by conserving water, noticing car } \\
\text { exhaust, picking up trash, avoiding littering, or any other } \\
\text { similar action? }\end{array}$ & 45 & 2 & 57.8 & 0.371 \\
\hline $\begin{array}{l}\text { c) Has your child shown an increased interest in the health or care } \\
\text { of plants either inside or outside of your home? }\end{array}$ & 46 & 1 & 71.7 & $0.004^{*}$ \\
\hline d) Has your child shown an increased interest in gardening? & 46 & 1 & 56.5 & 0.371 \\
\hline
\end{tabular}

Data were derived from a parental survey distributed after first-grade students in Iowa received lessons from the Growing in the Garden curriculum, which is a garden-based curriculum for kindergarten through third grade developed by Iowa State University Extension in 2000.

${ }^{*}$ Significant at $P<0.05$. 
related to the content, goals, and objectives for the nine lessons written for first grade in the GITG curriculum. Demographic information was also requested.

VALIDITy. Content validity of the survey instrument was established by a science education evaluation professional in the Department of Curriculum and Instruction at Iowa State University. Readability of the survey instrument was established by a survey professional at the Center for Survey Statistics and Methodology at Iowa State University. A reliability coefficient of 0.82 was determined for the 12 survey questions using Cronbach's $\alpha$ reliability test. The survey tool was purposefully kept brief and simple for ease in completion and to increase response rates. Surveys were translated into Spanish and Bosnian and distributed to parents whose primary language was not English.

Curriculum implementation. A youth specialist, trained in the GITG curriculum, from Iowa State University Extension implemented the curriculum in four first-grade classrooms located in two schools in north-central Iowa. First graders were considered ideal for a parental survey because of their varying degrees of reading and writing capabilities. In addition, the content of the first grade GITG curriculum closely follows local and national standards and benchmarks. Implementation of GITG curriculum lessons occurred from 11 Apr. to 4 May 2005. The use of one instructor in all classrooms provided a degree of consistency between lessons used across multiple classes. The classes ranged in size from 18 to 20 students, providing a total of 78 students in the study. Each class received three lessons, 45 to $60 \mathrm{~min}$ in duration, on three separate visits $\approx 2$ weeks apart. All students participated in the lessons entitled "Start with Seeds" and "My Totally Tasty Plants" (Table 2). Three of the four classrooms used "Designing Plants" as their last lesson; the fourth used "Being Loyal to the Soil." The lessons used were selected from nine first-grade lessons based on the preference of the classroom instructor and familiarity of content matter of the youth specialist. The number of lessons implemented was determined by the time allocated for the curricula by the classroom instructor. The youth specialist distributed packets containing a description of the project, parent surveys, and a teacher survey to the classroom teachers upon completion of the last lesson. Two weeks after the last lesson was completed, parents or guardians were requested to complete the survey and return it to the teacher. Teachers sent a reminder note card home 1 week after the surveys were distributed. Teachers returned completed surveys to the first author via a prepaid envelope. The youth specialist had no contact with the completed surveys.

Statistical analysis. Data were analyzed using SPSS (version 12.0 for Windows 98; SPSS, Chicago). Descriptive statistics included frequencies and percentages. Data collected from yes/no questions were converted into categorical values. Because of the dichotomous nature of the data and the nonsymmetrical population probability distribution, a sign test $(\alpha=0.05)$ was used to define significance of the number of positive or negative responses. Additional analysis for nonparametric correlation between question responses and demographic information was performed using chi-square analysis $(\alpha=0.05)$ and Kendall's Tau b (KTb; significant at $\geq 0.20$ ) in conjunction with crosstabulations.

\section{Results and discussion}

Of the 78 parental surveys distributed, 47 were returned, for a return rate of $60.2 \%$. A slightly higher percentage of female children $(57.4 \%)$ were represented by the returned surveys, with male children comprising $42.6 \%$ of the sample. Most respondents $(40.4 \%)$ live in small towns $(<5000$ residents $), 19.1 \%$ live in communities with 5 to 15,000 residents, and $8.5 \%$ live in communities with more than 25,000 residents. Almost one-third (31.9\%) did not respond to this particular question. A majority of the children were white $(78.7 \%)$ and nearly $20 \%$ were minority of either Hispanic $(10.6 \%)$ or Bosnian (10.6\%) ethnicity. About one-third $(35.6 \%)$ of respondents indicated their child qualified for free or reduced school lunch lunches, designating their annual income for a family of four at or less than $\$ 34,873$ (U.S. Department of Agriculture, 2005). These demographic results correspond closely with the overall composition of the state of Iowa with the exception of the ethnic distribution. The percentage of minority

Table 2. Descriptions of Growing in the Garden ${ }^{\mathrm{z}}$ lessons delivered to kindergarten (K) and first-grade students in Iowa participating in a curricular assessment project.

\begin{tabular}{|c|c|c|c|c|c|}
\hline Lesson Title & $\begin{array}{l}\text { Grade } \\
\text { level }\end{array}$ & Content objective & Life skill objective & Subjects & Survey Category \\
\hline Start with seeds & $\mathrm{K}$ & $\begin{array}{l}\text { Learn characteristics } \\
\text { of seeds }\end{array}$ & $\begin{array}{l}\text { Sorting and } \\
\text { experimenting }\end{array}$ & Science, language arts & Science, environment \\
\hline My totally tasty plant & 1 & $\begin{array}{l}\text { Develop awareness } \\
\text { of edible parts } \\
\text { of plants }\end{array}$ & Identification & Science, health, art & Science, nutrition \\
\hline Be loyal to the soil & 1 & $\begin{array}{l}\text { Understand that good } \\
\text { soil is limited in } \\
\text { nature and needs } \\
\text { to be protected }\end{array}$ & Responsibility & Science, math & Science, environment \\
\hline
\end{tabular}

${ }^{\mathrm{z}} \mathrm{A}$ garden-based curriculum for kindergarten through third grade developed by Iowa State University Extension in 2000. 
students was high when compared with the relatively low-minority population $(6.1 \%)$ throughout the state of Iowa (U.S. Census Bureau, 2005).

In addition to basic demographic information, the survey also included questions regarding the child's experience with gardening and cooking (Table 3). Many children had a flower $(59.6 \%)$ or vegetable $(23.4 \%)$ garden at home, but $14.9 \%$ came from homes lacking trees or shrubs, and $10.6 \%$ lived in a location without lawns. Nearly half the parents surveyed said they gardened with their child $(47.7 \%)$. The majority of parents $(78.7 \%)$ said they cooked with their child, and $56.7 \%$ of survey respondents indicated they did so at least once per week.

Two of the four science questions yielded significant positive responses (Table 1). The majority of parents $(75.6 \%)$ observed an increase in their child's interest in researching their questions. Eighty percent of respondents noted an increased ability to distinguish between living and nonliving things, which is a kindergarten through fourth-grade science content standard (National Science Foundation, 1999). The majority of students did not have an increased interest in the origin of their foods (plant vs. animal) or increased interest in the identification or names of plants. Each of the four lessons presented in this study contained a science theme, which may have contributed to the overall positive impact observed in the area of science.

No significant positive results were found concerning the four nutritional questions (Table 1 ). Three of the four questions received response rates of $59.6 \%, 50.0 \%$, and $45.7 \%$, respectively. Only $21.7 \%(P<0.001)$ of parents noticed an increase concerning the origin or food group designation of packaged food products. This statistically significant result was not surprising because the concept of packaged food origination was not presented in any of the four lessons out of nine used in this study. The result for this item provides support that the findings are linked to the lessons rather than other variables such as maturation of study participants.

Two of the four questions targeting environmental awareness were statistically significant at $71.7 \%$ and

Table 3. Number and proportion of responses to gardening and cooking questions from a 2005 survey sent to parents of first-grade students in Iowa receiving Growing in the Garden ${ }^{z}$ lessons.

\begin{tabular}{|c|c|c|}
\hline Question & Responses (n) & $\begin{array}{l}\text { Proportion of } \\
\text { responses (\%) }\end{array}$ \\
\hline a) The child's primary home has & 47 & 100.0 \\
\hline Vegetable garden & 11 & 23.4 \\
\hline Flower garden & 28 & 59.6 \\
\hline Container garden & 6 & 12.8 \\
\hline Trees or shrubs & 40 & 85.1 \\
\hline Lawn & 42 & 89.4 \\
\hline b) Do you garden with your child? & 44 & 100.0 \\
\hline No & 23 & 62.3 \\
\hline Yes & 21 & 47.7 \\
\hline \multicolumn{3}{|l|}{ How often } \\
\hline $4 \times$ per week or more & 0 & 0.0 \\
\hline $2-3 \times$ per week & 1 & 4.8 \\
\hline $1 \times$ per week & 4 & 19.0 \\
\hline $2 \times$ per month & 0 & 0.0 \\
\hline $1 \times$ per month & 1 & 4.8 \\
\hline Other & 11 & 52.4 \\
\hline Missing & 4 & 19.0 \\
\hline c) Do you cook with your child? & 47 & 100.0 \\
\hline No & 10 & 21.3 \\
\hline Yes & 37 & 78.7 \\
\hline \multicolumn{3}{|l|}{ How often } \\
\hline $4 \times$ per week or more & 7 & 18.9 \\
\hline $2-3 \times$ per week & 7 & 18.9 \\
\hline $1 \times$ per week & 7 & 18.9 \\
\hline $2 \times$ per month & 1 & 2.7 \\
\hline $1 \times$ per month & 3 & 8.1 \\
\hline Other & 7 & 18.9 \\
\hline Missing & 5 & 13.5 \\
\hline
\end{tabular}

${ }^{\mathrm{z}} \mathrm{A}$ garden-based curriculum for kindergarten through third grade developed by Iowa State University Extension in 2000

78.7\% (Table 1), whereas the remaining two questions had positive response rates of $57.8 \%$ and $56.5 \%$ respectively. Parents reported positive changes in their child's reactions and interests regarding environmental awareness after receiving GITG lessons, indicating that the curriculum likely impacted environmental awareness and interests of first-graders.

Correlations were found between three demographic categories and four of the 12 yes/no survey questions. Parents who indicated they did not garden with their child were less likely to observe their child exhibiting increased interest in origins of foods $\left(\chi^{2}=0.044, \mathrm{KTb}=0.307\right)$, interest in identification of plants $\left(\chi^{2}=0.025\right.$, $\mathrm{KTb}=0.343$ ), or respect for landscape plantings $\left(\chi^{2}=0.046, \mathrm{KTb}=0.301\right)$. Parents who indicated they did garden with their child and those who cooked with their child were more likely to observe an increased interest in gardening $\left(\chi^{2}=0.002,0.044 ; \mathrm{KTb}=\right.$
$0.468,0.301$ respectively) as opposed to parents who did not garden or cook with their children. Eighty percent of parents, including all parents of male children, indicated their child displayed an increased ability to distinguish between living and nonliving things, (Table 1 ). The $20 \%$ of parents who did not indicate a change all had female children $\left(\chi^{2}=0.004, \mathrm{KTb}=\right.$ 0.427). Possible explanations for reporting positive change in this area include increased attention to scientific abilities by parents of male students, advanced science ability by female students before exposure to the GITG lessons, or a difference in impact based on classroom delivery, all of which relate to issues of gender in the classroom (Sanders, 1997). No correlations were found relating to town size or economic status of the students and parental responses to survey questions. The limited number of correlations suggests that factors such as socioeconomic status, 
ethnicity, and gender did not influence the overall success of the lessons.

\section{Conclusion}

A statistical majority of parents indicated that three GITG lessons positively impacted the interests and awareness of first-graders in this study in the areas of science and environmental awareness. Each of the categories of science, nutrition, and environmental awareness received positive response rates in excess of $50 \%$ for at least one of the four questions presented per subject. The low percentage of parents who noticed change in nutritional awareness and interests supports the validity of the survey instrument as students received minimal exposure to nutritional lessons. The instrument developed to critique GITG was based on all nine lessons and not, specifically, the lessons taught. Other lessons within the GITG curriculum place greater emphasis on nutritional concepts. Other researchers have shown that participation in gardening programs do not necessarily lead to an increase in a child's preference toward fruit and vegetables (Poston et al., 2005). Koch et al. (2006) reported a significant increase in knowledge of the nutritional benefits of fruit and vegetables in elementary school children participating in a gardening program, but no significant differences in their attitudes toward fruit and vegetables.

Increased interest in gardening was noted in children with parents who garden or cook with their kids. It is interesting to note that parents who did not garden with their children found their children to be less interested in the origin of their foods, identifying plants, and respect for landscape plantings.

Time available for instruction is of concern when considering the effectiveness of any curriculum (Hong, 2001; Soloway et al., 2000). The amount of classroom time devoted to GITG lessons was limited in this study. The positive changes observed in awareness and interests after only $3 \mathrm{~h}$ of instruction were quite promising. Smith and Motsenbocker (2005) reported an increased science achievement score in only one of three classes participating in $12.5 \mathrm{~h}$ of gardenbased lessons. Increased contact hours may increase positive parental observations; however, other variables may contribute to the effectiveness of a curriculum more than time. The single most important factor that influences student achievement is the level of preparation and skill of the teacher (Armour-Thomas et al., 1989; Darling-Hammond, 1996; Ferguson, 1991; Lattery et al., 2002).

The use of a single instructor to implement the GITG lessons was considered a benefit to reduce instructor variability but could also mask the potential impact of a curriculum. The classroom teacher is familiar with subtleties of classroom dynamics, individual student needs and abilities, and is aware of children's backgrounds and prior knowledge that can be used to strengthen the learning experience.

Research in the area of horticulture education has many complications and confounding variables not present in the more quantitative research involving plants (Phibbs and Relf, 2005). Evaluation at this early age can be challenging, but the earlier a child is exposed to horticultural experiences, concepts, and ideas, the greater the potential for attitudinal or behavioral change (Lineberger and Zajicek, 2000).

Because of the relatively small sample size and the lack of a control group, the findings presented should not be generalized beyond the scope of the project, but rather used as a guide for future research. More assessments of garden-based curricula, including GITG, are needed to determine the impact of such curricula on the knowledge, attitudes, and behaviors of young children.

\section{Literature cited}

Armour-Thomas, E., C. Clay, R. Domanico, K. Bruno, and B. Allen. 1989. An outlier study of elementary and middle schools in New York City: Final report. New York City Board of Education, New York

Boudreau, D. 2005. Use of a parent questionnaire in emergent and early literacy assessment of preschool children. Language Speech Hearing Services Schools 36:33-47.

Briggs, M., S.A. Safaii, and D.L. Beall. 2003. Position of the American Dietetic Association, Society for Nutrition Education, and American School Food Services Association: Nutrition services: An essen- tial component of comprehensive school health programs. J. Amer. Dietetic Assn. 103:505-514.

Campbell, A.N., T.M. Waliczek, J.C. Bradley, J.M. Zajicek, and C.D. Townsend. 1997. The influence of activitybased environmental instruction on high school students' environmental attitudes. HortTechnology 7:309.

Criswell, R.J. and S.J. Criswell. 1995. Modeling alternative classroom assessment practices in teacher education coursework. J. Instructional Psychol. 22:190-194.

Darling-Hammond, L. 1996. The right to learn and the advancement of teaching: Research, policy, and practice for democratic education. Educ. Res. 25:5-17.

DeMarco, L.W., D. Relf, and A. McDaniel. 1999. Integrating gardening into the elementary school curriculum. HortTechnology 9:276-281.

Dirks, A.E. and K. Orvis. 2005. An evaluation of the junior master gardener program in third grade classrooms. HortTechnology 15:443-447.

Doak, J.L. and A.D. Chapman. 1994. Educational reform in early elementary assessment. J. Instructional Psychol. 21:8-14.

Ferguson, R.F. 1991. Paying of public education: New evidence on how and why money matters. Harvard J. Legislation 28:465-498.

Gilroy, M. 2002. Waking up students' math/science attitudes and achievement. Educ. Dig. 68:39-45.

Grahm, H., D.L. Beall, M. Lussier, P. McLaughlin, and S. Zidenberg-Cherr. 2005. Use of school gardens in academic instruction. J. Nutr. Educ. Behav. 37: 147-151.

Hong, L.K. 2001. Too many intrusions on instructional time. Phi Delta Kappan 82:712-715.

Iowa State University Extension. 2001. Growing in the garden K-3 curriculum: Latest news. 8 Oct. 2005. <www. extension.iastate.edu/Growinginthegarden/ news.html>.

Klemmer, C.D., T.M. Waliczek, and J.M. Zajicek. 2005. Development of a science achievement evaluation instrument for a school garden program. Hort Technology 15:433-438.

Koch, S., S. Lineberger, and J.M. Zajicek. 2005. Can an educational program on the nutritional benefits of citrus fruit positively influence the nutritional attitudes of children? HortTechnology 15:468-471.

Koch, S., T.M. Waliczek, and J.M. Zajicek. 2006. The effect of summer garden 
program on the nutritional knowledge, attitudes, and behaviors of children. Hort Technology 16:620-625.

Lattery, M.J., J. Lemberger, and B. Herzog. 2002. Impact of the science and technology curriculum in the Oshkosh area school district. Sch. Sci. Math. 102:124-137.

Lineberger, S.E. and J.M. Zajicek. 2000. School gardens: Can a hands-on teaching tool affect student's attitudes and behaviors regarding fruit and vegetables? HortTechnology 10:593-597.

McGuinn, C. and D. Relf. 2001. A profile of juvenile offenders in a vocational horticulture classroom. HortTechnology 11:427-432.

Meyer, M.H., N.N. Hegland, and P. Fairbourne. 2001. Junior Master Gardener programs in Minnesota. HortTechnology 11:665-667.

Midden, K.S. and J. Chambers. 2000. An evaluation of a children's garden in developing a greater sensitivity of the environment in preschool children. HortTechnology 10:385-390.

Mohrmann, P. 1999. Planting the seeds of science. Instructor Intermediate 108: 25-30.

Morris, J.L. and S. Zindenberg-Cherr. 2002. Garden-enhanced nutrition curriculum improves fourth-grade school children's knowledge of nutrition and preferences for some vegetables. J. Amer. Dietetic Assn. 102:91-93.

Motsenbocker, C. and L. Smith. 2003. A garden-based science curriculum can impact environmental awareness of elementary school students. HortScience 38:836(abstr.).

National Science Foundation. 1999. Content standards: K-4. p. 135 In: National science education standards. National Research Council (eds.). National Academy Press, Washington, DC.

O'Callaghan, A.M. 2005. Creating a school gardens program in the challenging environment of Las Vegas, Nevada. Hort Technology 15:429-433.

Phibbs, E.J. and D. Relf. 2005. Improving research on youth gardening. HortTechnology 15:425-428.

Poston, S.A., C.A. Shoemaker, and D.A. Dzewaltowski. 2005. A comparison of a gardening and nutrition program with a standard nutrition program in an out-ofschool setting. HortTechnology 15:463467.

Rahm, J. 1999. Is that really science? A look at the science practices of an innercity youth gardening program. Proc Amer. Educ. Res. Assn. Annu. Mtg. Montreal April 19-23:1-27.

Relf, P.D. and V.I. Lohr. 2003. Human issues in horticulture. HortScience 38:984-993.

Sanders, J. 1997. Teacher education and gender equity. Eric Document Reproduction Serv. no. ED 408277. 5 Sept 2007. <http://www.ericdigests.org/1998-1/ gender.htm $>$.

Scruggs, T.E. and M.A. Mastropieri. 1995. Science education for students with behavioral disorders. Educ. Treat. Child. 18:322-335.

Skelly, S.M. and J.M. Zajicek. 1998. The effects of an interdisciplinary garden program on the environmental attitudes of elementary school students. HortTechnology 8:579-583.

Smith, L.L. and C.E. Motsenbocker. 2005. Impact of hands-on science through school gardening in Louisiana public elementary schools. HortTechnology 15:439-443.

Soloway, E., C. Norris, P. Blumenfeld, B. Fishman, J. Krajcik, and R. Marx. 2000. The three T's of elementary education. Commun. Assn. Computing Machinery 12:15-19.

Taylor, A.F., F.E. Kuo, and W.C. Sullivan. 2001. Coping with attention deficit disorder: The surprising connection to green play settings. Environ. Behav. 33: 54-77.

Texas A\&M University Extension. 2005. Junior Master Gardener program. 8 Oct. 2005. <www.jmgkids.us>.

Twiss, J., J. Dickenson, S. Duma, T. Kleinman, H. Paulsen, and L. Rilveria. 2003. Community gardens: Lessons learned from California healthy cities and communities. Amer. J. Public Health 93:1435-1439.

U.S. Census Bureau. 2005. State and country quickfacts: Iowa. 27 Nov. 2005. $<$ http://quickfacts.census.gov/qfd/ states/19000.html>.

U.S. Department of Agriculture. 2005. Child nutrition programs: Income eligibility guidelines 2005-2006. 23 Sept. 2005. $<$ www.fns.usda.gov/cnd/Governance/ notices/iegs/IEG05-06.pdf>.

Wells, N.M. 2000. At home with nature: Effects of 'greenness" on children's cognitive functioning. Environ. Behav. 32: 775-795.

Welsh, D.F., L.A. Whittlesey, R.L. Seagraves, G.W. Hall, and M.M. Harlow. 1999. Junior Master Gardeners program addresses youth needs. J. Ext. 37(3). 8 Oct. 2005. <www.joe.org/joe/1999june/ iwl.html>. 